\title{
Oral Sodium Bicarbonate Supplementation Does Not Affect Serum Calcification Propensity in Patients with Chronic Kidney Disease and Chronic Metabolic Acidosis
}

\author{
Christof Aigner ${ }^{a}$ Daniel Cejka ${ }^{b}$ Christopher Sliber ${ }^{a, c}$ \\ Melanie Fraunschiel $^{d} \quad$ Gere Sunder-Plassmann $^{\text {a }}$ Martina Gaggl ${ }^{a}$ \\ a Division of Nephrology and Dialysis, Department of Medicine III, Medical University \\ Vienna, Vienna, Austria; b Department of Medicine III, Nephrology, Hypertension, \\ Transplantation and Rheumatology, Ordensklinikum Linz at Krankenhaus der Elisabethinen,

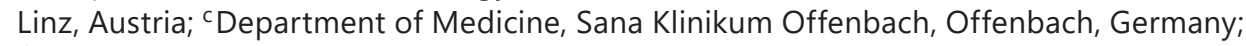 \\ dITSC - IT Systems \& Communications, Section IT4Science, Medical University of Vienna, \\ Vienna, Austria
}

\section{Keywords}

Cardiovascular disease $\cdot T_{50} \cdot$ Metabolic acidosis $\cdot$ Chronic kidney disease $\cdot$ Bicarbonate

\begin{abstract}
Background: Cardiovascular disease is the leading cause of death in patients with chronic kidney disease (CKD) and metabolic acidosis might accelerate vascular calcification. The $T_{50}$ calcification inhibition test ( $T_{50}$-test) is a global functional test analyzing the overall propensity of calcification in serum, and low $\mathrm{T}_{50}$-time is associated with progressive aortic stiffening and with all-cause mortality in non-dialysis CKD, dialysis, and transplant patients. Low serum bicarbonate is associated with a short $T_{50}$-time and alkali supplementation could be a simple modifier of calcification propensity. The aim of this study was to investigate the short-term effect of oral sodium bicarbonate supplementation on $\mathrm{T}_{50}$-time in CKD patients. Material and Methods: The SoBic-study is an ongoing randomized-controlled trial in CKD-G3 and G4 patients with chronic metabolic acidosis (serum $\mathrm{HCO}_{3}{ }^{-} \leq 21 \mathrm{mmol} / \mathrm{L}$ ), in which patients are randomized to either achieve serum $\mathrm{HCO}_{3}{ }^{-}$levels of $24 \pm 1 \mathrm{mmol} / \mathrm{L}$ (intervention group) or $20 \pm$ $1 \mathrm{mmol} / \mathrm{L}$ (rescue group). The effect of bicarbonate treatment on $\mathrm{T}_{50}$-time was assessed. $\boldsymbol{R e}$ sults: The study cohort consisted of 35 (14 female) patients aged $57( \pm 15)$ years, and 18 were randomized to the intervention group. The mean $T_{50}$-time was 275 ( \pm 64$) \mathrm{min}$. After 4 weeks,
\end{abstract}




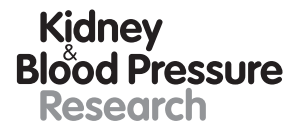

Kidney
Blood Pressure
Research

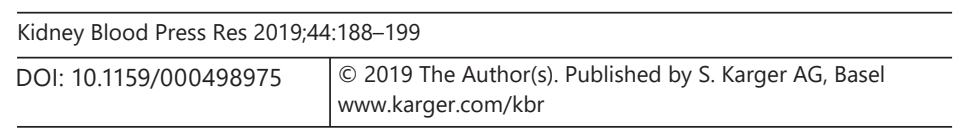

Aigner et al.: $\mathrm{T}_{50}$-Time and Sodium Bicarbonate Supplementation in CKD

the mean change of $T_{50}$-time was $4( \pm 69) \mathrm{min}$ in the intervention group and $18 \mathrm{~min}( \pm 56)$ in the rescue group ( $\beta=-25 ; 95 \% \mathrm{Cl}:-71$ to $22 ; p=0.298$ ). Moreover, change of serum bicarbonate in individual patients was not associated with change in $\mathrm{T}_{50}$-time, analyzed by regression analysis. Change of serum phosphate had a significant impact on change of $\mathrm{T}_{50}$-time ( $\beta=-145$; 95\% Cl: -237 to -52$)$. Conclusion: Oral sodium bicarbonate supplementation showed no effect on $\mathrm{T}_{50}$-time in acidotic CKD patients.

(C) 2019 The Author(s)

Published by S. Karger AG, Basel

\section{Introduction}

Cardiovascular disease is the leading cause of death in patients with chronic kidney disease (CKD) [1] and metabolic acidosis is thought to accelerate progression of both, cardiovascular disease and CKD [2-10]. Derangements of calcium and phosphorus homeostasis, parathyroid hormone and metabolic bone disease are summarized as the "chronic-kidneydisease - mineral and bone disorder - CKD-MBD," a syndrome associated with severe vascular calcification [11]. Vascular calcification is strongly related with morbidity and mortality in CKD patients $[12,13]$. Numerous promoters (phosphate, calcium, metabolic acidosis) and inhibitors (Fetuin-A, pyrophosphate, magnesium, bicarbonate) of calcification have been identified (reviewed in Shroff et al. [14]), many of which cannot be measured in clinical routine (i.e., Fetuin $\mathrm{A}$, pyrophosphate). The $\mathrm{T}_{50}$ calcification inhibition test $\left(\mathrm{T}_{50}\right.$-test) is a global functional test analyzing the overall propensity for calcification of patient serum. The in vitro diagnostic test measures the conversion (or "maturation") of primary to secondary calciprotein particles (CPP) in serum. The half-maximum time for this conversion is called " $\mathrm{T}_{50}$ " and is given in minutes (min) [15]. Low $\mathrm{T}_{50}$-time (i.e., low resistance towards calcification) is associated with progressive aortic stiffening and with all-cause mortality in nondialysis CKD [16], dialysis [17], and transplant patients [18, 19].

Interventions to modify vascular calcification and to subsequently reduce mortality in CKD patients are of great importance. Aside from other potential strategies, intervening on serum bicarbonate $\left(\mathrm{HCO}_{3}{ }^{-}\right)$, which is a strong inhibitor of calciprotein particle formation in vitro, appears to be a reasonable and economically feasible intervention to improve the $\mathrm{T}_{50}$-time in CKD patients (Pasch A et al., FR-P0401; Buchkremer F et al., Fr-PO 437, ASN 2016). In CKD patients, correction of acid-base disturbance with oral sodium bicarbonate supplementation is part of routine clinical care. However, the evidence on patient-level outcomes to support this practice is scarce [20-24], and its impact on reducing morbidity and mortality in CKD is unknown.

The aim of this study was to investigate the short-term effect of oral sodium bicarbonate supplementation in patients with CKD stage 3 and 4 with chronic metabolic acidosis (serum bicarbonate $\leq 21 \mathrm{mmol} / \mathrm{L}$ ) on the calcification propensity in serum, measured by the $\mathrm{T}_{50}$-test. We hypothesized that patients in the interventional group will have a significant prolongation of their $\mathrm{T}_{50}$-time (i.e., increase in resistance to calcification) from baseline to week 4 and will have a significantly longer $\mathrm{T}_{50}$-time at week 4 compared to the rescue group.

\section{Material and Methods}

The SoBic-study (EUDRACT: 2012-001824-36, 7/12/2012) [25] is an ongoing randomized-controlled trial in CKD-G3 and G4 patients with chronic metabolic acidosis (serum $\mathrm{HCO}_{3}{ }^{-} \leq 21 \mathrm{mmol} / \mathrm{L}$ ) at the Renal Outpatient Clinic at the Medical University of Vienna. 


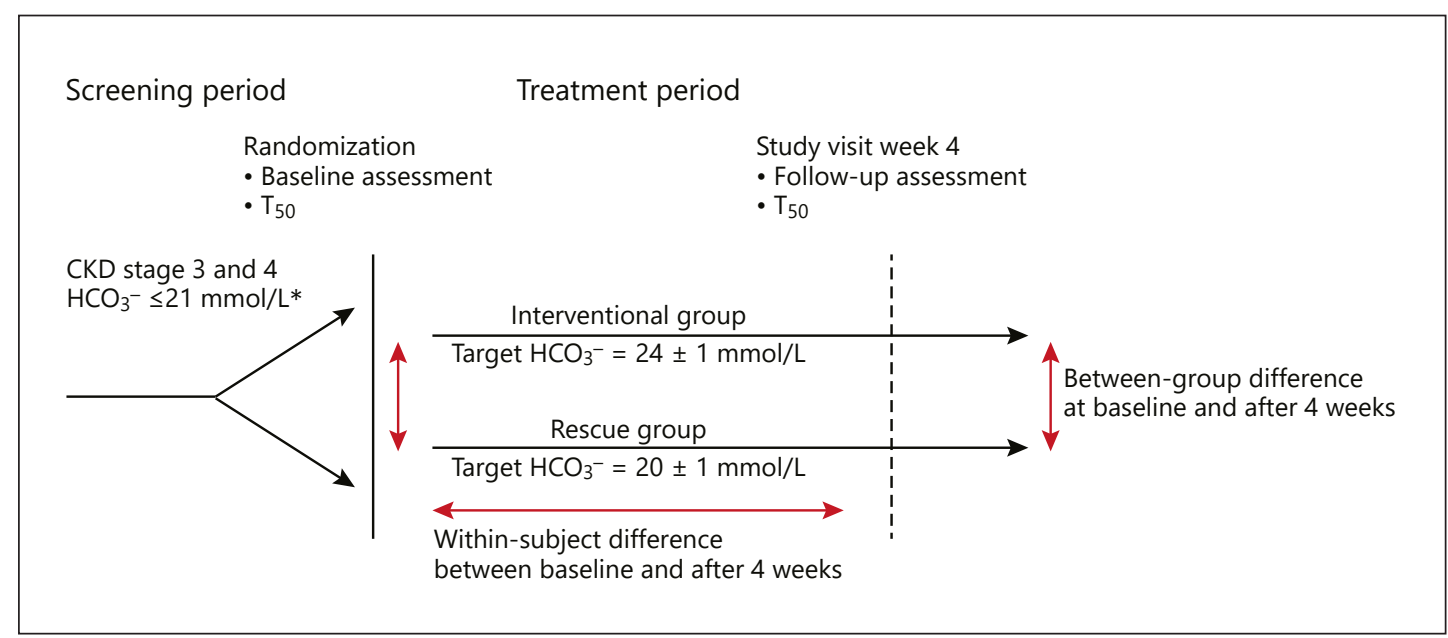

Fig. 1. Trial profile. * Two consecutive measurements at least 1 day apart.

The aim of the parent study is to evaluate the effect of normalizing serum bicarbonate $\left(\mathrm{HCO}_{3}^{-}\right)$ levels to $24 \pm 1 \mathrm{mmol} / \mathrm{L}$ (intervention group) compared to serum bicarbonate $\left(\mathrm{HCO}_{3}{ }^{-}\right)$levels of $20 \pm 1 \mathrm{mmol} / \mathrm{L}$ (rescue group) on renal function (MDRD-eGFR) over 2 years. Inclusion criteria were age $>18$ years, estimated glomerular filtration rate (eGFR) of 60 to $15 \mathrm{~mL} / \mathrm{min}$ per $1.73 \mathrm{~m}^{2}$, venous serum $\mathrm{HCO}_{3}{ }^{-}$of $\leq 21 \mathrm{mmol} / \mathrm{L}$ on two consecutive measurements (at least 1 day apart), and stable clinical condition. Exclusion criteria were malignant disease or within 5 years of successful treatment of such, morbid obesity (body mass index $>40 \mathrm{~kg} / \mathrm{m}^{2}$ ), chronic inflammation ( $C$ reactive protein $>10 \mathrm{mg} / \mathrm{dL}$, reference: $<0.5 \mathrm{~g} / \mathrm{dL}$ ), current immunosuppressive medication, poorly controlled blood pressure $(>150 / 90 \mathrm{~mm} \mathrm{Hg}$ despite the use of four agents), overt congestive heart failure, or known peanut or soy allergy (both ingredients of study medication). Dependent on randomization, patients were treated with Nephrotrans ${ }^{\circledR}$ 840 mg tablets (sodium bicarbonate; MEDICE Pharma Pütter GmbH \& Co. KG, Iserlohn, Germany) according to a treatment algorithm [25]. For patients receiving sodium bicarbonate supplementation the dose was constant for the 4 weeks of follow-up in this study.

The primary outcome of the current study was the change of $\mathrm{T}_{50}$-time ( $\mathrm{min}$ ) between baseline and week 4 within patients and the difference between the $\mathrm{T}_{50}$-time between subjects in the intervention group and rescue group (Fig. 1). All patients gave written informed consent, the study is in line with the Declaration of Helsinki, and the Ethics Committee of the Medical University of Vienna approved the current study.

\section{Study Cohort and Time Line}

This analysis included all 38 patients enrolled in the SoBic-study as of September 2017. We obtained demographic and medical information as well as a laboratory analysis at randomization as detailed elsewhere (visit 1 and 2 of the SoBic-study) [25]. After 4 weeks all patients underwent visit 3 (week 4) for a subsequent laboratory investigation, assessment of vital signs, body weight, and adverse events (Fig. 1).

We determined the $\mathrm{T}_{50}$-time in serum specimens drawn at baseline and week 4 out of biobank samples immediately stored at $-80^{\circ} \mathrm{C}$ [25]. Potential relevant covariates like eGFR, serum phosphate, serum calcium, serum magnesium, comorbidities, co-medication, and demographic data has already been obtained during regular SoBic-study visits [25]. 


\section{Kidney \\ Blood Pressure \\ Research}

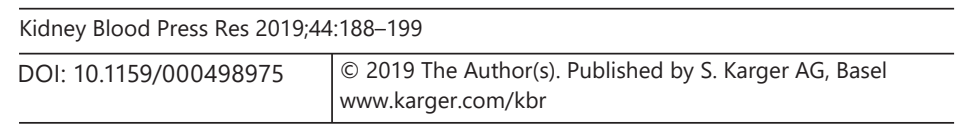

Aigner et al.: $\mathrm{T}_{50}$-Time and Sodium Bicarbonate Supplementation in CKD

\section{Laboratory Measures}

$\mathrm{T}_{50}$-time was determined by Calciscon AG, Bern, Switzerland as described previously [15]. In brief, the calcification propensity test is an in vitro nano-particle assay, which measures the time of conversion of primary to secondary CPPs. Serum samples were supersaturated with calcium and phosphate to increase their final concentrations by 10 and $6 \mathrm{~mm}$, respectively. Secondary CPP formation time $\left(\mathrm{T}_{50}\right.$-time) was measured by a nephelostar nephelometer (BMG Labtech, Ortenberg, Germany). Other parameters were measured as detailed in Gaggl et al. [25].

The main outcome, change of $\mathrm{T}_{50}$-time (min, $\Delta \mathrm{T}_{50}$-time), was calculated as $\mathrm{T}_{50}$-time at week 4 minus baseline $\mathrm{T}_{50}$-time. Similarly, we calculated change of $\mathrm{HCO}_{3}{ }^{-}\left(\mathrm{mmol} / \mathrm{L}, \Delta \mathrm{HCO}_{3}{ }^{-}\right)$, change of eGFR ( $\mathrm{mL} / \mathrm{min}$ per $1.73 \mathrm{~m}^{2}, \Delta$ eGFR), change of serum albumin $(\mathrm{g} / \mathrm{L}, \Delta$ serum albumin) change of serum calcium (mmol/L, $\Delta$ serum calcium), change of serum magnesium (mmol/L, $\Delta$ serum magnesium), and change of serum phosphate (mmol/L, $\Delta$ serum phosphate).

\section{Statistical Analysis}

We presented descriptive statistics as mean and standard deviation $( \pm \mathrm{SD})$ and median and interquartile range (IQR), respectively, as appropriate. Firstly, imbalances between the investigational and rescue group were examined visually and by Student's $t$ test and WilcoxonMann-Whitney test, respectively, depending on test assumptions. To test changes of parameters in individuals during the 4 weeks we performed paired Student's $t$ test or a Wilcoxon signed-rank test as appropriate. To analyze correlation between serum bicarbonate and other laboratory parameters we performed Spearman correlations $\left(r_{\mathrm{ho}}\right)$ and visualized the relation by means of scatterplots.

Secondly, for the intention to treat analysis we calculated two different regression models using treatment group (reference $=$ rescue group) as the predictor: To assess the differences between groups after 4 weeks we predicted $\mathrm{T}_{50}$-time (outcome), and to account for withinsubject change we predicted $\Delta \mathrm{T}_{50}$-time (outcome). Although randomization creates equal covariate distribution in both study groups by expectation, we adjusted for variables with observed minor differences at baseline and for strong predictors of the outcome (i.e., eGFR, age, and baseline serum bicarbonate).

Thirdly, we analyzed changes of serum parameters to explore the effect on the change of $\mathrm{T}_{50}$-time from baseline to week $4\left(\Delta \mathrm{T}_{50}\right.$-time) by regression analysis, ignoring group randomization of study subjects.

All results are presented as point estimates and corresponding $95 \%$ confidence intervals $(95 \% \mathrm{CI})$, and all results with a $p$ value lower than 0.05 were considered statistically significant. All statistical analysis was performed with R (R Core Team (2016). "R: A language and environment for statistical computing"; R Foundation for Statistical Computing, Vienna, Austria; https://www.R-project.org/).

\section{Results}

As of September 2017, 38 patients were enrolled in the SoBic-study, of which 3 were excluded from this analysis, because of missing $\mathrm{T}_{50}$-time. Of the 35 remaining patients, 14 were female $(40 \%)$ and the mean age was $57( \pm 15)$ years. Further basic demographic information is given in Table 1 for the 18 subjects randomized to the intervention group, and for the 17 subjects of the rescue group.

The median baseline serum bicarbonate was similar in the intervention group and in the rescue group (19.20 mmol/L [IQR: 17.90-19.85] vs. $19.80 \mathrm{mmol} / \mathrm{L}$ [IQR: 17.70-20.5, $p=$ $0.34]$ ) and so was the median eGFR (23.30 mL/min per $1.72 \mathrm{~m}^{2}$ [IQR: 19.22-25.87] vs. 24.40 
Table 1. Patients' demographic information and laboratory parameters

\begin{tabular}{|c|c|c|c|c|}
\hline & Intervention group & Rescue group & $p$ value $^{1}$ & All \\
\hline Age, years & $59.94 \pm 12.46$ & $53.12 \pm 17.74$ & 0.20 & $56.63 \pm 15.42$ \\
\hline Female, yes & $6(33.3 \%)$ & $8(47.1 \%)$ & 0.50 & $14(40 \%)$ \\
\hline $\mathrm{BMI}^{2}, \mathrm{~kg} / \mathrm{m}^{2}$ & $27.16 \pm 4.45$ & $26.31 \pm 3.76$ & 0.55 & $26.73 \pm 4.10$ \\
\hline \multicolumn{5}{|l|}{ Medical history } \\
\hline Arterial hypertension & $18(100 \%)$ & $16(94.1 \%)$ & 0.49 & $34(97 \%)$ \\
\hline Hyperlipidemia & $3(16.7 \%)$ & $4(23.5 \%)$ & 0.69 & $7(20 \%)$ \\
\hline Diabetes mellitus & $7(38.9 \%)$ & $3(17.6 \%)$ & 0.26 & $10(28.6 \%)$ \\
\hline Cardiovascular disease & $3(16.7 \%)$ & $1(5.9 \%)$ & 0.60 & $4(11.4 \%)$ \\
\hline Congestive heart failure & $1(5.6 \%)$ & $2(11.8 \%)$ & 0.60 & $3(8.6 \%)$ \\
\hline Peripheral arterial disease & $3(16.7 \%)$ & $3(17.6 \%)$ & 1.0 & $6(17.1 \%)$ \\
\hline COPD & 0 & $1(5.9 \%)$ & 0.49 & $1(2.9 \%)$ \\
\hline \multicolumn{5}{|l|}{ Baseline } \\
\hline Serum bicarbonate, mmol/L & $18.78 \pm 1.59$ & $19.28 \pm 1.55$ & 0.35 & $19.02 \pm 1.57$ \\
\hline $\mathrm{T}_{50}$-time, $\min$ & $269 \pm 63$ & $281 \pm 67$ & 0.60 & $275 \pm 64$ \\
\hline eGFR, mL/min per $1.73 \mathrm{~m}^{2}$ & $23.64 \pm 5.87$ & $27.45 \pm 10.05$ & 0.19 & $25.49 \pm 8.28$ \\
\hline Serum sodium, $\mathrm{mmol} / \mathrm{L}$ & $140 \pm 3.03$ & $139 \pm 2.6$ & 0.31 & $139 \pm 2.8$ \\
\hline Serum chloride, mmol/L & $106 \pm 3.23$ & $105 \pm 3.13$ & 0.36 & $106 \pm 3.2$ \\
\hline Serum potassium, $\mathrm{mmol} / \mathrm{L}$ & $4.83 \pm 0.47$ & $4.94 \pm 0.61$ & 0.54 & $4.88 \pm 0.54$ \\
\hline Serum calcium, mmol/L & $2.26 \pm 0.15$ & $2.29 \pm 0.13$ & 0.55 & $2.27 \pm 0.14$ \\
\hline Serum phosphate, mmol/L & $1.11 \pm 0.22$ & $1.19 \pm 0.26$ & 0.35 & $1.15 \pm 0.24$ \\
\hline Serum magnesium, mmol/L & $0.78 \pm 0.12$ & $0.81 \pm 0.10$ & 0.52 & $0.80 \pm 0.11$ \\
\hline Serum albumin, g/L & $41 \pm 3.7$ & $41 \pm 4.7$ & 0.63 & $41 \pm 4.2$ \\
\hline Urine sodium ${ }^{3}, \mathrm{mmol}^{2} 24 \mathrm{~h}$ & $188 \pm 92$ & $167 \pm 69$ & 0.48 & $179 \pm 82$ \\
\hline Urine $\mathrm{pH}$ & $5.36 \pm 0.59$ & $5.35 \pm 0.63$ & 0.97 & $5.36 \pm 0.6$ \\
\hline \multicolumn{5}{|l|}{ Week 4} \\
\hline Serum bicarbonate, mmol/L & $21.61^{* *} \pm 1.4$ & $20.95^{* * \pm 1.66}$ & 0.21 & $21.29 \pm 1.55$ \\
\hline $\mathrm{T}_{50}$-time, $\min$ & $273 \pm 85$ & $298 \pm 48$ & 0.29 & $286 \pm 70$ \\
\hline eGFR, mL/min per $1.73 \mathrm{~m}^{2}$ & $22.94 \pm 5.77$ & $28.76 \pm 12.14$ & 0.09 & $25.77 \pm 9.37$ \\
\hline Serum sodium, mmol/L & $140 \pm 3.13$ & $140 * \pm 2.4$ & 0.95 & $140 \pm 2.7$ \\
\hline Serum chloride, mmol/L & $104 * \pm 3.96$ & $104 \pm 3.3$ & 0.93 & $104 \pm 3.6$ \\
\hline Serum potassium, mmol/L & $4.70 \pm 0.44$ & $4.85 \pm 0.48$ & 0.37 & $4.77 \pm 0.46$ \\
\hline Serum calcium, mmol/L & $2.29 \pm 0.19$ & $2.29 \pm 0.14$ & 1.00 & $2.29 \pm 0.16$ \\
\hline Serum phosphate, mmol/L & $1.11 \pm 0.28$ & $1.12 \pm 0.21$ & 0.91 & $1.11 \pm 0.25$ \\
\hline Serum magnesium, mmol/L & $0.78 \pm 0.10$ & $0.80 \pm 0.10$ & 0.47 & $0.79 \pm 0.10$ \\
\hline Serum albumin, $\mathrm{mmol} / \mathrm{L}$ & $41 \pm 3.5$ & $41 \pm 4.9$ & 0.84 & $41 \pm 4.2$ \\
\hline Urine sodium ${ }^{4}, \mathrm{mmol} / 24 \mathrm{~h}$ & $212 \pm 81$ & $174 \pm 82$ & 0.19 & $194 \pm 82$ \\
\hline Urine $\mathrm{pH}$ & $6.39 * * \pm 0.95$ & $6.0 * \pm 0.97$ & 0.24 & $6.20 \pm 1.0$ \\
\hline
\end{tabular}

Values present mean \pm standard deviation and count (percent), respectively. BMI, body mass index; eGFR, estimated glomerular filtration rate; COPD, chronic obstructive pulmonary disease. ${ }^{1}$ Independent sample Student's $t$ test for continuous variables and $\chi^{2}$ test for categorical variables, respectively; ${ }^{2} 1$ missing; ${ }^{3} 4$ missing; ${ }^{4} 3$ missing. ${ }^{*} p<0.05$ and ${ }^{* *} p<0.001$, respectively, for paired $t$ test.

$\mathrm{mL} / \mathrm{min}$ per $1.72 \mathrm{~m}^{2}$ [IQR: $\left.21.20-34.30, p=0.43\right]$ ). The mean serum phosphate was 1.11 $( \pm 0.22) \mathrm{mmol} / \mathrm{L}$ in the intervention group and $1.19( \pm 0.26)$ in the rescue group $(p=0.35)$.

Other baseline parameters were approximately similar between both groups. According to the pre-specified treatment algorithm all patients in the intervention group received oral sodium bicarbonate, but only 9 patients in the rescue group (Fig. 2). However, one patient from the intervention group stopped taking sodium bicarbonate 8 days before the study visit because of problems with the study medication supply. At week 4, patients randomized to the 
Fig. 2. Relation between change of $\mathrm{T}_{50}$-time and change of serum bicarbonate in the intervention group (grey dots) and the rescue group (black dots). The daily oral sodium bicarbonate dose is depicted by dot size.

Fig. 3. Relation between change of $\mathrm{T}_{50}$-time and change of serum bicarbonate in the intervention group (grey dots) and the rescue group (black dots). The daily oral sodium bicarbonate dose is depicted by dot size.
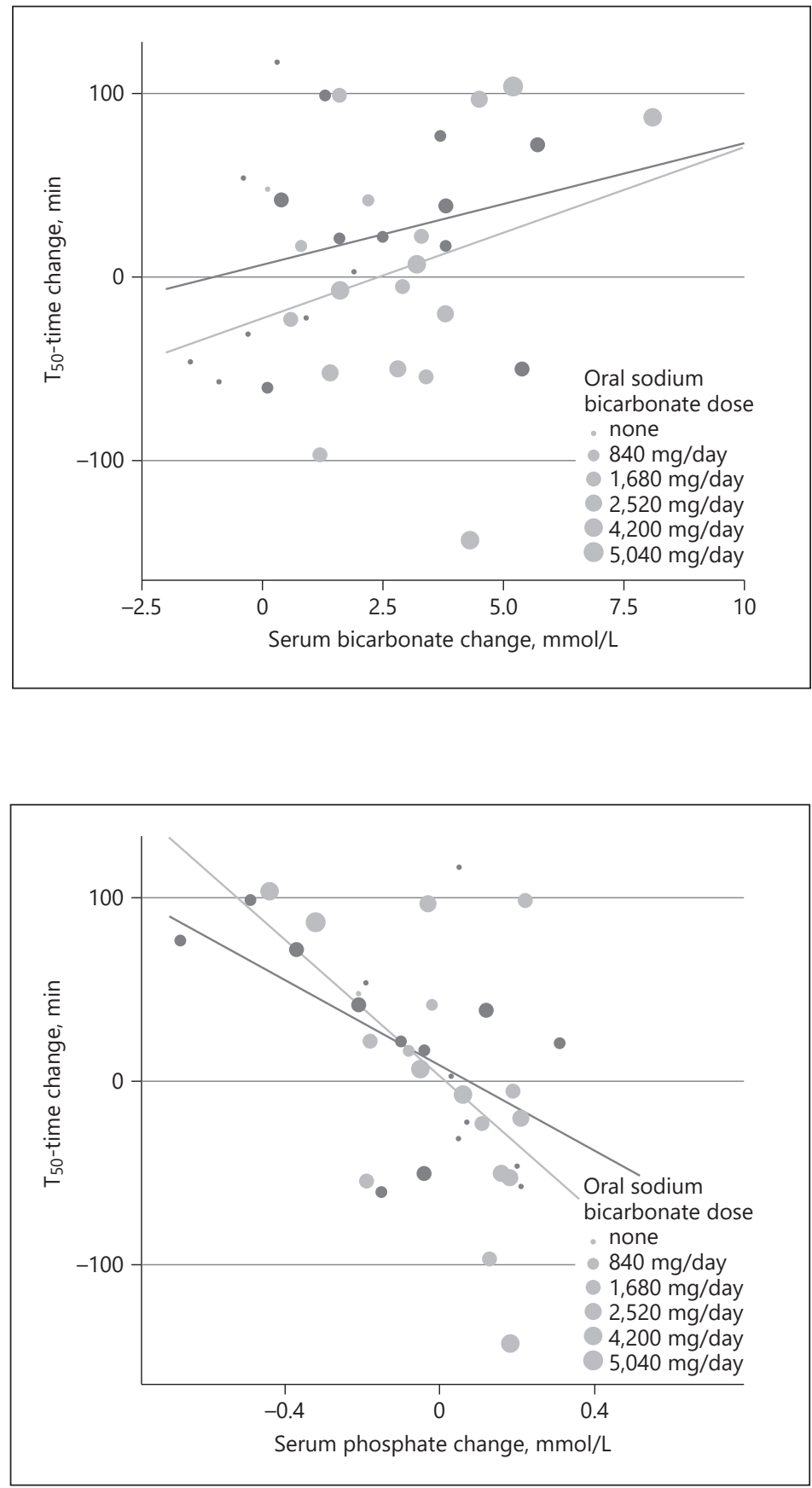

intervention group received a median dose of oral sodium bicarbonate of 4,200 (IQR: 2,520$5,040) \mathrm{mg}$ per day (mean $[ \pm \mathrm{SD}]=45[ \pm 20] \mathrm{mg}$ per kilogram bodyweight/day), whereas the rescue group received a median dose of 1,680 (IQR: $1,680-2,520)$ mg per day (mean $[ \pm S D]=$ 15 [ \pm 14$]$ mg per kilogram bodyweight/day).

The overall $\mathrm{T}_{50}$-time was $275( \pm 15) \mathrm{min}$ at baseline, $269( \pm 63)$ min and $281( \pm 67) \mathrm{min}$ for the intervention and rescue group, respectively. Overall, baseline $\mathrm{T}_{50}$-time was not correlated with age and body mass index, and did not differ with regard to gender. With respect to baseline laboratory measurements $\mathrm{T}_{50}$-time was not correlated with serum bicarbonate 


\section{Kidney \\ Blood Pressure \\ Research}

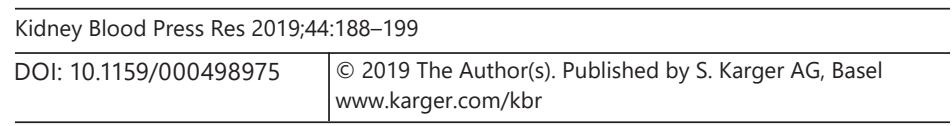

Aigner et al.: $\mathrm{T}_{50}$-Time and Sodium Bicarbonate Supplementation in CKD

$\left(r_{\mathrm{ho}}=0.29, p=0.10\right)$, eGFR $\left(r_{\mathrm{ho}}=0.22, p=0.10\right)$, serum calcium $\left(r_{\mathrm{ho}}=0.21, p=0.22\right)$, serum $\operatorname{albumin}\left(r_{\mathrm{ho}}=-0.07, p=0.750\right)$, or serum magnesium $\left(r_{\mathrm{ho}}=0.10, p=0.60\right)$. In contrast, baseline serum phosphate was strongly correlated with baseline $\mathrm{T}_{50}$-time $\left(r_{\mathrm{ho}}=-0.61, p<0.001\right)$. Correlation patterns were identical at week 4 , but the correlation between serum phosphate and $\mathrm{T}_{50}$-time was weakened $\left(r_{\mathrm{ho}}=-0.49, p=0.003\right)$.

After 4 weeks, the overall mean change of $\mathrm{T}_{50}$-time was $11( \pm 62) \mathrm{min}, 4( \pm 69) \mathrm{min}$ in the intervention group and $18 \mathrm{~min}( \pm 56)$ in the rescue group. Subjects randomized to the intervention group did not have a different $\mathrm{T}_{50}$-time after 4 weeks compared to those from the rescues group ( $\beta_{\text {crude }}=-25 ; 95 \%$ CI: -71 to $\left.22 ; p=0.30\right)$. Adjustment for baseline renal function, baseline serum bicarbonate and age did not change the null-effect $\left(\beta_{\mathrm{adj}}=-15 ; 95 \% \mathrm{CI}\right.$ : -64 to $\left.34 ; p=0.60\right)$.

When individual changes of $\mathrm{T}_{50}$-time were taken into account $\left(\Delta \mathrm{T}_{50}\right.$-time), there was still no difference observed between intervention and rescue group in the crude $\left(\beta_{\text {crude }}=-14\right.$, $95 \%$ CI: -55 to $28 ; p=0.53$ ) and adjusted model ( $\beta_{\text {adj }}=-10 ; 95 \%$ CI: -51 to $32 ; p=0.65$; Fig. 2 ).

Furthermore, we explored the effect of the change in known promoters and inhibitors on $\Delta \mathrm{T}_{50}$-time: Interestingly, from modulators of the $\mathrm{T}_{50}$-time suggested by in vitro experiments [26], only $\Delta$ serum phosphate (mean change $-0.004( \pm 0.2) \mathrm{mmol} / \mathrm{L})$ had a significant impact on $\Delta \mathrm{T}_{50}$-time (Fig. 3). For subjects with a $1 \mathrm{mmol} / \mathrm{L}$ increase of serum phosphate from baseline to week 4 the model adjusted for $\Delta$ serum bicarbonate suggested a decrease of 141 (95\% CI: -226 to -56 ) min of $\mathrm{T}_{50}$-time from baseline to week 4 (model 5). When age and $\Delta$ eGFR were added into the model (model 7), the magnitude of the effect slightly increased $\left(\beta_{\mathrm{adj}}=-145 ; 95 \% \mathrm{CI}:-237\right.$ to -52$)$.

\section{Discussion}

In this randomized trial in patients with CKD stage 3 to 4 and overt metabolic acidosis we tested the effect of sodium bicarbonate treatment on vascular calcification propensity $\left(\mathrm{T}_{50^{-}}\right.$ time). Our study showed that a high dose of oral sodium bicarbonate (median $4.2 \mathrm{~g} /$ day vs. $1.7 \mathrm{~g} /$ day) did not increase $\mathrm{T}_{50}$-time at week 4 (high resistance towards calcification) relative to baseline $\mathrm{T}_{50}$-time. Although there was neither at baseline nor at week 4 a correlation between serum bicarbonate and $\mathrm{T}_{50}$-time, our finding might be partly caused by the small mean treatment contrast of $0.75 \mathrm{mmol} / \mathrm{L}$ serum bicarbonate between study groups at week 4. Since the mean increase in plasma bicarbonate in the overall cohort was $2.8 \mathrm{mmol} / \mathrm{L}$ (range: $0.1-8.1$ ) we subsequently explored the effect of $\Delta$ serum bicarbonate on $\Delta \mathrm{T}_{50}$-time. Our data does not support positive associations observed in in vitro [15] and observational studies [17, 18] between serum bicarbonate and $\mathrm{T}_{50}$-time (Table 2 , adjusted model 7 ). Ignoring statistical significance, the magnitude of the here observed effect is probably of little clinical relevance, because of the relatively narrow range of serum bicarbonate encountered in clinical practice. In a previous study, all-cause mortality in CKD patients with a mean $\mathrm{T}_{50}$-time of $227 \pm 44$ was 2.2 to 4.7 (depending on adjustment set) times the mortality in CKD patients with a $\mathrm{T}_{50}$-time of $434 \pm 58 \mathrm{~min}$.[16] Given our point estimate of $2 \mathrm{~min}$ change of $\mathrm{T}_{50}$-time per $\mathrm{mmol} / \mathrm{L}$ change of serum bicarbonate, we theoretically would have to increase the serum bicarbonate concentration by $100 \mathrm{mmol} / \mathrm{L}$ to reduce all-cause mortality, when extrapolating our results to findings reported by Smith et al. [16].

Our results are in line with a randomized cross-over study in acidotic (serum $\mathrm{HCO}_{3}{ }^{-}<22$ $\mathrm{mmol} / \mathrm{L}$ ) CKD $3 \mathrm{~b}$ and 4 patients receiving sodium bicarbonate over 6 weeks to target a serum $\mathrm{HCO}_{3}{ }^{-}$of $\geq 23 \mathrm{mmol} / \mathrm{L}$ by Kendrick et al. [27]. $\mathrm{T}_{50}$-time, which was a secondary outcome, was unaffected by the intervention, even though the difference between serum $\mathrm{HCO}_{3}{ }^{-}$in the intervention and control group was more distinct compared to our study (mean difference 2.7 $\mathrm{mEq} / \mathrm{L}, 95 \% \mathrm{CI}: 0.9,4.6)$. However, they also observed a significant increase in serum phos- 
Table 2. Change of $\mathrm{T}_{50}$-time with respect to various laboratory parameters

\begin{tabular}{|c|c|c|c|}
\hline & Beta & $95 \% \mathrm{CI}$ & $p$ value \\
\hline \multicolumn{4}{|l|}{ Crude model } \\
\hline$\Delta$ serum bicarbonate & 6.32 & -3.51 to 16.16 & 0.22 \\
\hline \multicolumn{4}{|l|}{ Adjusted model 1} \\
\hline$\Delta$ serum bicarbonate & 5.95 & -4.04 to 15.94 & 0.25 \\
\hline$\Delta$ eGFR & 1.22 & -2.53 to 4.96 & 0.53 \\
\hline \multicolumn{4}{|l|}{ Adjusted model 2} \\
\hline$\Delta$ serum bicarbonate & 7.12 & -1.96 to 16.20 & 0.13 \\
\hline Age & -1.67 & -2.91 to -0.42 & 0.01 \\
\hline \multicolumn{4}{|l|}{ Adjusted model 3} \\
\hline$\Delta$ serum bicarbonate & 5.56 & -4.36 to 15.47 & 0.28 \\
\hline$\Delta$ serum magnesium & -155.35 & -442.72 to 132.02 & 0.30 \\
\hline \multicolumn{4}{|l|}{ Adjusted model 4} \\
\hline$\Delta$ serum bicarbonate & 8.10 & -3.30 to 19.49 & 0.17 \\
\hline$\Delta$ serum calcium & -84.14 & -349.82 to 181.54 & 0.54 \\
\hline \multicolumn{4}{|l|}{ Adjusted model 5} \\
\hline$\Delta$ serum bicarbonate & 1.34 & -7.83 to 10.52 & 0.78 \\
\hline$\Delta$ serum phosphate & -140.59 & -225.70 to -55.49 & 0.003 \\
\hline \multicolumn{4}{|l|}{ Adjusted model 6} \\
\hline$\Delta$ serum bicarbonate & 6.23 & -3.72 to 16.19 & 0.23 \\
\hline$\Delta$ serum albumin & -2.80 & -13.54 to 7.94 & 0.61 \\
\hline \multicolumn{4}{|l|}{ Adjusted model 7} \\
\hline$\Delta$ serum bicarbonate & 2.22 & -6.37 to 10.80 & 0.62 \\
\hline$\Delta$ eGFR & -1.11 & -4.67 to 2.46 & 0.55 \\
\hline Age & -1.41 & -2.55 to -0.28 & 0.02 \\
\hline$\Delta$ serum phosphate & -144.68 & -237.33 to -52.03 & 0.01 \\
\hline
\end{tabular}

95\% CI, 95\% confidence interval; $\Delta$, change between baseline and week 4; eGFR, estimated glomerular filtration rate $\left(\mathrm{mL} / \mathrm{min}\right.$ per $\left.1.73 \mathrm{~m}^{2}\right) ; \Delta$ serum bicarbonate $(\mathrm{mmol} / \mathrm{L})$; age (years); $\Delta$ serum magnesium (mmol/L); $\Delta$ serum calcium (mmol/L); $\Delta$ serum phosphate (mmol/L); $\Delta$ serum albumin (g/L).

phate, which is in contrast to ours and a study by Chen et al. [28]. They speculated based on animal experiments that acidosis might induce a tubular phosphate leak. Neither group allocation (Fig. 3) nor $\Delta$ serum $\mathrm{HCO}_{3}{ }^{-}$had a significant effect on $\Delta$ serum phosphate (adjusted for $\triangle$ eGFR) in our study (data not shown).

In vitro experiments suggested that other serum electrolytes than serum bicarbonate influence the $\mathrm{T}_{50}$-time: recently, Bressendorff et al. demonstrated that magnesium supplementation compared to placebo in 36 patients with CKD 3 and 4 over 8 weeks changed the $\mathrm{T}_{50}$-time on average by $40 \mathrm{~min}$ [29]. Although the clinical relevance of the observed effect is still unclear, it is worth mentioning that the result reached statistical significance with a similar sample size and standard deviation of $\mathrm{T}_{50}$-time to the here presented study. Based on that we can argue that our study was not underpowered to avoid a type II error.

Among all measured serum electrolytes, only $\Delta$ serum phosphate had a strong association with $\Delta \mathrm{T}_{50}$-time. An increase by $1 \mathrm{mmol} / \mathrm{L}$ of serum phosphate from baseline to week 4 led to a decrease of $\mathrm{T}_{50}$-time by 145 (95\% CI: -237 to -52$)$ min. This result compares well 


\section{Kidney \\ Blood Pressure \\ Research}

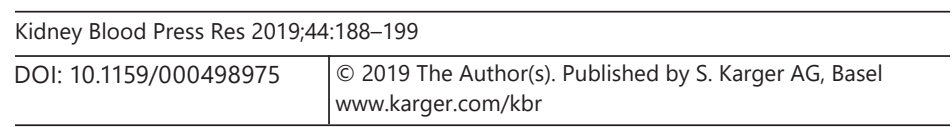

with several other lines of research, which had identified hyperphosphatemia levels as the number one driver of vascular calcification in CKD patients (reviewed in Ritter et al. [30]). In cell cultures high phosphate levels transform vascular smooth muscle cells into osteoblastlike cells [31], and cells from CKD patients lack inherent pathways to prevent calcification compared to healthy control cells [32]. Importantly, there is evidence that current treatment practice in CKD is hampering natural preventive mechanisms against vascular calcification in CKD patients. Zhang et al. [33] showed in 5/6 nephrectomized male Sprague-Dawley rats that acidic milieu prevents calcitriol-induced calcium absorption to vascular smooth muscles cells, which is in line with previously reported results by Mendoza et al. [34]. Similarly, alkalization in a high phosphorus environment induced mRNA and protein expression of L-type calcium channel $\beta 3$-subunit on rat vascular smooth muscle cells, furthermore suggesting increased calcium uptake [35]. In small studies in humans $\mathrm{NH}_{4} \mathrm{Cl}$-induced acidosis led to phosphaturia [36, 37] and the observed increase of serum phosphate after correction of metabolic acidosis with sodium bicarbonate by Kendrick et al. [27] adds another important fact to the discussion. These highly interesting aspects of the complex CKD syndrome suggest that the gradual development of metabolic acidosis with decreasing renal function could actually mitigate vascular calcification. Notably, in those animal models acidosis was induced by $\mathrm{NH}_{4} \mathrm{Cl}$ enhanced water, which is known to be only partially comparable with human uremic acidosis [38]. However, results from analysis of the Chronic Renal Insufficiency Cohort (CIRC) suggest that there is no association between parameters of cardiac structure and serum bicarbonate after adjustment for demographics, traditional cardiovascular disease risk factors, medications, and kidney function [39]. Additionally, the risk of heart failure and mortality is actually increased in patients with persistent high serum bicarbonate levels $(>26$ $\mathrm{mmol} / \mathrm{L}$ ) compared to those with bicarbonate concentrations between 22 and $26 \mathrm{mmol} / \mathrm{L}$ [40]. In view of this complex interplay, it is worth mentioning that we observed a 3.5-times lower $\Delta \mathrm{T}_{50}$-time in the intervention group compared to the rescue group, although the change was only of small magnitude and the difference statistical insignificant. However, it might be thinkable, that the "mineralization paradox [41] - the inverse relation of bone mineralization and vascular calcification - in dialysis patients is partly driven by the therapeutic compensation of acidosis with high bicarbonate dialysate concentrations [42-44] in combination with vitamin D treatment [11] and insufficient control of hyperphosphatemia [45]. Furthermore, high serum bicarbonate levels are associated with higher mortality in dialysis [46] and non-dialysis CKD populations [47].

Several limitations are worth mentioning: Our study might have yielded more distinct results by a longer follow-up period, such as 8 or 12 weeks like presented by others $[48,49]$. However, in theory increasing serum bicarbonate should have had an instantaneous effect on the $\mathrm{T}_{50^{-}}$-time and after 4 weeks of high dose sodium bicarbonate treatment a change in $\mathrm{T}_{50^{-}}$ time should have been apparent, given that our hypothesis was true.

We cannot exclude the possibility that due to multiple testing, we observed the association between $\Delta$ serum phosphate and $\Delta \mathrm{T}_{50}$-time out of chance.

In conclusion, our study showed no effect of a 4-week oral sodium bicarbonate supplementation on vascular calcification propensity $\left(\mathrm{T}_{50}\right.$-time) in patients with metabolic acidosis and CKD stage 3 to 4 . In this cohort serum bicarbonate concentrations were neither at baseline nor after 4 weeks correlated with $\mathrm{T}_{50}$-times. Furthermore, our study suggests that a change in serum phosphate is the most potent modulator of the $\mathrm{T}_{50}$-time. 


\section{Acknowledgements}

The authors wish to acknowledge the help of Candace Joefield-Roka, Marlies DamesLudwig, Miriam Kunst, Ingrid Jachimow, Sylvia Taxer, Karin Voith, Danica Doric, Maria Villaluz, Gabi Rath, Violeta Tanacovic by collecting data and helping to conduct the SoBicstudy.

\section{Statement of Ethics}

Subjects (or their parents or guardians) have given their written informed consent. The study protocol has been approved by the research institute's committee on human research.

\section{Disclosure Statement}

The authors have nothing to disclose.

\section{Funding Sources}

This project was funded by the Hochschuljubiläumsstiftung der Stadt Wien (project number: H-354297/2017; principle investigator: Martina Gaggl) and the "MedizinischWissenschaftliche Fonds des Bürgermeisters der Bundeshauptstadt Wien" (project number: 17082; principle investigator: Martina Gaggl).

Study medication was provided by the manufacturer (MEDICE Pharma Pütter GmbH \& Co. KG, Iserlohn, Germany) free of cost. The sponsor had no role in the conduction of that study and preparation of the manuscript.

\section{Author Contributions}

M.G., G.S.-P., and D.C. designed the study; C.A., C.S., M.F., M.G., and G.S.-P. conducted the study and collected the data; C.A., M.G., D.C., and G.S.-P. drafted the manuscript.

\section{References}

1 Go AS, Chertow GM, Fan D, McCulloch CE, Hsu CY. Chronic kidney disease and the risks of death, cardiovascular events, and hospitalization. N Engl J Med. 2004 Sep;351(13):1296-305.

2 Raj S, Scott DR, Nguyen T, Sachs G, Kraut JA. Acid stress increases gene expression of proinflammatory cytokines in Madin-Darby canine kidney cells. Am J Physiol Renal Physiol. 2013 Jan;304(1):F41-8.

3 Recio-Mayoral A, Banerjee D, Streather C, Kaski JC. Endothelial dysfunction, inflammation and atherosclerosis in chronic kidney disease-a cross-sectional study of predialysis, dialysis and kidney-transplantation patients. Atherosclerosis. 2011 Jun;216(2):446-51.

4 Akchurin OM, Kaskel F. Update on inflammation in chronic kidney disease. Blood Purif. 2015;39(1-3):84-92.

5 Rao M, Wong C, Kanetsky P, Girndt M, Stenvinkel P, Reilly M, et al. Cytokine gene polymorphism and progression of renal and cardiovascular diseases. Kidney Int. 2007 Sep;72(5):549-56.

6 Lotspeich WD. Renal Hypertrophy in Metabolic Acidosis and Its Relation to Ammonia Excretion. Am J Physiol. 1965 Jun;208(6):1135-42.

7 Nath KA, Hostetter MK, Hostetter TH. Pathophysiology of chronic tubulo-interstitial disease in rats. Interactions of dietary acid load, ammonia, and complement component C3. J Clin Invest. 1985 Aug;76(2):667-75. 


\section{Kidney \\ Blood Pressure \\ Research}

\begin{tabular}{l|l}
\hline Kidney Blood Press Res 2019:44:188-199 \\
\hline DOI: 10.1159/000498975 & $\begin{array}{l}\text { @ 2019 The Author(s). Published by S. Karger AG, Basel } \\
\text { www.karger.com/kbr }\end{array}$ \\
\hline
\end{tabular}

Aigner et al.: $\mathrm{T}_{50}$-Time and Sodium Bicarbonate Supplementation in CKD

8 Freund DM, Prenni JE, Curthoys NP. Response of the mitochondrial proteome of rat renal proximal convoluted tubules to chronic metabolic acidosis. Am J Physiol Renal Physiol. 2013 Jan;304(2):F145-55.

9 Wesson DE, Jo CH, Simoni J. Angiotensin II receptors mediate increased distal nephron acidification caused by acid retention. Kidney Int. 2012 Dec;82(11):1184-94.

10 Kraut JA, Madias NE. Metabolic Acidosis of CKD: an Update. Am J Kidney Dis. 2016 Feb;67(2):307-17.

11 KDIGO. Kidney Disease: Improving Global Outcomes (KDIGO) 2017 Clinical Practice Guideline Update for the Diagnosis, Evaluation, Prevention, and Treatment of Chronic Kidney Disease-Mineral and Bone Disorder (CKD-MBD). Kidney Int Suppl. 2017;7(1):1-59.

12 Okuno S, Ishimura E, Kitatani K, Fujino Y, Kohno K, Maeno Y, et al. Presence of abdominal aortic calcification is significantly associated with all-cause and cardiovascular mortality in maintenance hemodialysis patients. Am J Kidney Dis. 2007 Mar;49(3):417-25.

13 Blacher J, Guerin AP, Pannier B, Marchais SJ, London GM. Arterial calcifications, arterial stiffness, and cardiovascular risk in end-stage renal disease. Hypertension. 2001 0ct;38(4):938-42.

14 Shroff R, Long DA, Shanahan C. Mechanistic insights into vascular calcification in CKD. J Am Soc Nephrol. 2013 Feb;24(2):179-89.

15 Pasch A, Farese S, Gräber S, Wald J, Richtering W, Floege J, et al. Nanoparticle-based test measures overall propensity for calcification in serum. J Am Soc Nephrol. 2012 Oct;23(10):1744-52.

16 Smith ER, Ford ML, Tomlinson LA, Bodenham E, McMahon LP, Farese S, et al. Serum calcification propensity predicts all-cause mortality in predialysis CKD. J Am Soc Nephrol. 2014 Feb;25(2):339-48.

17 Pasch A, Block GA, Bachtler M, Smith ER, Jahnen-Dechent W, Arampatzis S, et al. Blood Calcification Propensity, Cardiovascular Events, and Survival in Patients Receiving Hemodialysis in the EVOLVE Trial. Clin J Am Soc Nephrol. 2017 Feb;12(2):315-22.

18 Keyzer CA, de Borst MH, van den Berg E, Jahnen-Dechent W, Arampatzis S, Farese S, et al. Calcification Propensity and Survival among Renal Transplant Recipients. J Am Soc Nephrol. 2016 Jan;27(1):239-48.

19 Dahle DO, Åsberg A, Hartmann A, Holdaas H, Bachtler M, Jenssen TG, et al. Serum Calcification Propensity Is a Strong and Independent Determinant of Cardiac and All-Cause Mortality in Kidney Transplant Recipients. Am J Transplant. 2016 Jan;16(1):204-12.

20 KDIGO. Kidney Disease: Improving Global Outcomes (KDIGO) 2012 Clinical Practice Guideline for the Evaluation and Management of Chronic Kidney Disease; Chapter 3: Management of progression and complications of CKD; 3.4. Acidosis. Kidney Int Suppl. 2013;3:73-90.

21 Wesson DE, Simoni J. Acid retention during kidney failure induces endothelin and aldosterone production which lead to progressive GFR decline, a situation ameliorated by alkali diet. Kidney Int. 2010 Dec;78(11):1128-35.

22 Goraya N, Simoni J, Jo C, Wesson DE. Dietary acid reduction with fruits and vegetables or bicarbonate attenuates kidney injury in patients with a moderately reduced glomerular filtration rate due to hypertensive nephropathy. Kidney Int. 2012 Jan;81(1):86-93.

23 Goraya N, Simoni J, Jo CH, Wesson DE. A comparison of treating metabolic acidosis in CKD stage 4 hypertensive kidney disease with fruits and vegetables or sodium bicarbonate. Clin J Am Soc Nephrol. 2013 Mar;8(3):371-81.

24 Goraya N, Simoni J, Jo CH, Wesson DE. Treatment of metabolic acidosis in patients with stage 3 chronic kidney disease with fruits and vegetables or oral bicarbonate reduces urine angiotensinogen and preserves glomerular filtration rate. Kidney Int. 2014 Nov;86(5):1031-8.

25 Gaggl M, Cejka D, Plischke M, Heinze G, Fraunschiel M, Schmidt A, et al. Effect of oral sodium bicarbonate supplementation on progression of chronic kidney disease in patients with chronic metabolic acidosis: study protocol for a randomized controlled trial (SoBic-Study). Trials. 2013 Jul;14(1):196.

26 Pasch A. Novel assessments of systemic calcification propensity. Curr Opin Nephrol Hypertens. 2016 Jul; 25(4):278-84.

27 Kendrick J, Shah P, Andrews E, You Z, Nowak K, Pasch A, et al. Effect of Treatment of Metabolic Acidosis on Vascular Endothelial Function in Patients with CKD: A Pilot Randomized Cross-Over Study. Clin J Am Soc Nephrol. 2018 Oct;13(10):1463-70.

28 Chen W, Melamed ML, Hostetter TH, Bauer C, Raff AC, Almudevar AL, et al. Effect of oral sodium bicarbonate on fibroblast growth factor-23 in patients with chronic kidney disease: a pilot study. BMC Nephrol. 2016 Aug; 17(1):114.

29 Bressendorff I, Hansen D, Schou M, Silver B, Pasch A, Bouchelouche P, et al. Oral Magnesium Supplementation in Chronic Kidney Disease Stages 3 and 4: Efficacy, Safety, and Effect on Serum Calcification PropensityA Prospective Randomized Double-Blinded Placebo-Controlled Clinical Trial. Kidney Int Rep. 2016 Dec;2(3): 380-9.

30 Ritter CS, Slatopolsky E. Phosphate Toxicity in CKD: The Killer among Us. Clin J Am Soc Nephrol. 2016 Jun; 11(6):1088-100.

31 Lau WL, Festing MH, Giachelli CM. Phosphate and vascular calcification: emerging role of the sodiumdependent phosphate co-transporter PiT-1. Thromb Haemost. 2010 Sep;104(3):464-70.

32 Shroff RC, McNair R, Skepper JN, Figg N, Schurgers LJ, Deanfield J, et al. Chronic mineral dysregulation promotes vascular smooth muscle cell adaptation and extracellular matrix calcification. J Am Soc Nephrol. 2010 Jan; 21(1):103-12.

33 Zhang S, Xu J, Feng Y, Zhang J, Cui L, Zhang H, et al. Extracellular acidosis suppresses calcification of vascular smooth muscle cells by inhibiting calcium influx via L-type calcium channels. Clin Exp Hypertens. 2018;40(4): $370-7$. 
34 Mendoza FJ, Lopez I, Montes de Oca A, Perez J, Rodriguez M, Aguilera-Tejero E. Metabolic acidosis inhibits soft tissue calcification in uremic rats. Kidney Int. 2008 Feb;73(4):407-14.

35 Bai YL, Xu JS, Tian T, Zhang JX, Cui LW, Zhang HR, et al. [Effect and mechanism of intermittent alkaline stimulation on high phosphorus induced calcification in vascular smooth muscle cells of rats]. Zhonghua Xin Xue Guan Bing Za Zhi. 2017 Jun;45(6):519-25.

36 Krapf R, Vetsch R, Vetsch W, Hulter HN. Chronic metabolic acidosis increases the serum concentration of 1,25-dihydroxyvitamin $\mathrm{D}$ in humans by stimulating its production rate. Critical role of acidosis-induced renal hypophosphatemia. J Clin Invest. 1992 Dec;90(6):2456-63.

37 Lemann J Jr, Litzow JR, Lennon EJ. Studies of the mechanism by which chronic metabolic acidosis augments urinary calcium excretion in man. J Clin Invest. 1967 Aug;46(8):1318-28.

38 Oh MS. New perspectives on acid-base balance. Semin Dial. 2000 Jul-Aug;13(4):212-9.

39 Dobre M, Roy J, Tao K, Anderson AH, Bansal N, Chen J, et al.; CRIC Study Investigators. Serum Bicarbonate and Structural and Functional Cardiac Abnormalities in Chronic Kidney Disease - A Report from the Chronic Renal Insufficiency Cohort Study. Am J Nephrol. 2016;43(6):411-20.

40 Dobre M, Yang W, Pan Q, Appel L, Bellovich K, Chen J, et al.: Persistent high serum bicarbonate and the risk of heart failure in patients with chronic kidney disease (CKD): A report from the Chronic Renal Insufficiency Cohort (CRIC) study. J Am Heart Assoc. 2015 Apr 20;4(4). pii: e001599.

41 Cai MM, Smith ER, Tan SJ, Hewitson TD, Holt SG. The Role of Secondary Calciprotein Particles in the Mineralisation Paradox of Chronic Kidney Disease. Calcif Tissue Int. 2017 Dec;101(6):570-80.

42 Kalantar-Zadeh K, Mehrotra R, Fouque D, Kopple JD. Metabolic acidosis and malnutrition-inflammation complex syndrome in chronic renal failure. Semin Dial. 2004 Nov-Dec;17(6):455-65.

43 Misra M. Pro: higher serum bicarbonate in dialysis patients is protective. Nephrol Dial Transplant. 2016 Aug; 31(8):1220-4.

44 Chauveau P, Rigothier C, Combe C. Con: higher serum bicarbonate in dialysis patients is protective. Nephrol Dial Transplant. 2016 Aug;31(8):1226-9.

45 Sherman RA. Hyperphosphatemia in Dialysis Patients: Beyond Nonadherence to Diet and Binders. Am J Kidney Dis. 2016 Feb;67(2):182-6.

46 Tentori F, Karaboyas A, Robinson BM, Morgenstern H, Zhang J, Sen A, et al. Association of dialysate bicarbonate concentration with mortality in the Dialysis Outcomes and Practice Patterns Study (DOPPS). Am J Kidney Dis. 2013 Oct;62(4):738-46.

47 Navaneethan SD, Schold JD, Arrigain S, Jolly SE, Wehbe E, Raina R, et al. Serum bicarbonate and mortality in stage 3 and stage 4 chronic kidney disease. Clin J Am Soc Nephrol. 2011 Oct;6(10):2395-402.

48 Pruijm M, Lu Y, Megdiche F, Piskunowicz M, Milani B, Stuber M, et al. Serum calcification propensity is associated with renal tissue oxygenation and resistive index in patients with arterial hypertension or chronic kidney disease. J Hypertens. 2017 Oct;35(10):2044-52.

49 Bristow SM, Gamble GD, Pasch A, O'Neill WC, Stewart A, Horne AM, et al.: Acute and 3-month effects of calcium carbonate on the calcification propensity of serum and regulators of vascular calcification: secondary analysis of a randomized controlled trial. Osteoporos Int. 2016 Mar;27(3):1209-16. 